\title{
Trends of Development of Higher Education in Generations Theory in Digital Global Economy
}

\author{
Irina Savelyeva*, Oksana Falchenko, Victor Kovalev, and Olga Pliusnina \\ Ural State University of Economics, Foreign Economic Activity Department, 6201448 Marta, 62, Ekaterinburg, Russia
}

\begin{abstract}
The article studies the tendencies of the development of higher education in the era of the digital global economy on the basis of the interdisciplinary approach. A method of critical analysis is used to promote the disclosure of contradictions between the trends in the development of the digital global economy and the state of higher education at the present stage, as well as the method of interpretation that allows us to come closer to understanding the tasks that the higher education system must solve through studying the characteristics of the current generation of students. An interpretation of the features of the modern educational process in the era of digital economy through the prism of the theory of generations (The Strauss-Howe Generational Theory) is given. The problem of search for actual models of higher education is investigated, and the necessity of finding ways of adapting higher education to the global challenges of modernity in the situation of reducing the influence of traditional teaching technologies on the younger generation is proved.
\end{abstract}

\section{Introduction}

Higher education at the present stage is undergoing serious changes related to the growing processes of globalization and the digitalization of socio-economic systems in the light of the rapid development of modern information technologies. The question of adapting the higher education system to the needs of the digital global economy is being updated. The Internet is gradually forming a new educational space which is breaking the usual learning patterns. Existing models of education and traditional educational technologies are becoming less and less in demand; they are replaced by new digital solutions.

The problem of finding models of higher education that are adequate to the needs of today is being updated in light of the theory of generations (The Strauss-Howe Generational Theory) which demonstrates the contradictory nature of the traditional model inherent in the modern higher school in Russia, the needs of modern youth, which is the basis for the development of human capital in the era of the digital economy .

The main objectives of this article are to examine trends in higher education and the problems of higher education in the digital global economy, as well as the rationale for the transformation of higher education through the prism of the theory of generations (The Strauss-Howe generational theory).

\section{Trends in the development of higher education in the era of the digital economy}

Problems in education in the 21 st century, according to Colin N. Power, will be determined by three global processes: inequality between countries, international migration and the development of new information and communication technologies [1]. Noting the rapid growth of private and open higher education institutions, as well as the growing competition in this field in the international arena, the author claims an identity crisis faced by universities around the world.

A serious challenge for modern higher education is the change in the ecosystem of society in the digital global economy, which inevitably entails a change in the social order in terms of higher education. The digital economy places high demands on the training of personnel, which modern educational programs and training technologies must meet.

The transition to the digital economy in Russia will be one of the main factors of GDP growth: until 2025 digital technologies will account for 19 to $34 \%$ of the total increase in Russian GDP [2]. Among the factors of digitalization one of the key roles should be played by the formation and development of the system of education, innovation and science.

In the works of foreign authors D. Knight [3], H. de Wit, F. Hunter [4; 5], J. Hudzik [6] and others, the tendencies of globalization processes are investigated. The direction of development of modern higher education in different countries of the world sets a number of global trends, such as the rapid development of the internationalization of education, the emergence and growing influence of international educational standards, the growth of the number of international educational programs and the strengthening of academic

* Corresponding author: irinasavelyeva2008@yandex.ru 
mobility. Researchers also note such features of the development of higher education as the emerging phenomenon of extraterritorial faculties and virtual departments, increasing interest in international certification and accreditation, as well as international certification of educational programs, etc. $[7 ; 8 ; 9 ; 10$; 11].

The digitization of the economy carries a multitude of economic and social benefits, one of which, according to McKinsey, is the decline in cost and the increased availability of mass education.

The digitization of the economy changes the context and resources of higher education, determines the prospects for modern higher education, which makes a radical revision of the traditional model of higher education. The rapid development of digital technologies leads to the emergence of new forms of organization of university activities, such as educational hubs, network communities, information and educational platforms, etc. Digitalization leads to the rapid development of open educational resources with varying combinations of training.

Many digital solutions in the field of higher education are successfully implemented by leading universities in the world (examples of fundamentally new approaches to learning can serve as MOOCs courses - "Massive Open Online Courses"). Thanks to modern digital technologies, higher education is becoming more accessible, due to the growing number of LMS distance-learning platforms (LMS, or Learning Management System).

Turning to the research of McKinsey, we note that Russia in terms of digitalization of the education sector is approaching the global level and contributing to GDP at the level of $2 \%$ per year [2].

Observing the achievements of developed countries in the digitization of higher education, the natural question arises: how ready is the Russian higher education system for the challenges of the digital economy and how do universities adapt to the changing needs of modern youth? It seems interesting to comprehend the need and direction of changes in higher education in terms of the needs of modern students in the digital age.

\section{The problem of generations and higher education for young people}

The problem of generations is the subject of many popular theories, but so far this topic has not been fully explored. Despite the fact that there is no single approach to the periodization and classification of generations in the scientific literature, there is an opinion that it is necessary to take into account the specifics of different generations, as well as use other methods and tools in cooperation with today's younger generation than with the previous ones.

For the purposes of this study, we will adhere to the classification of the generations of Neil Howe and William Strauss, proposed in 1991 [12]. According to this theory the cycle of generations consists of four types of people and is repeated every 80 years (Table 1). It should be noted that between generations there are no clear boundaries; people born at the junction of dates (three years before, three years after) are called "generation echoes".

Table 1. Periodization of generations [13].

\begin{tabular}{|c|c|}
\hline Generational Labels & Dates \\
\hline Mature Generation & $1925-1945$ \\
\hline Boom Generation & $1946-1964$ \\
\hline Generation X & $1965-1980$ \\
\hline Millennial Generation (Generation Y) & $1981-2000$ \\
\hline Generation Z (Digital natives) & $2001-$ present \\
\hline
\end{tabular}

Differences between generations, traditionally defined as the Baby Boom generation, the $\mathrm{X}$ generation, the $\mathrm{Y}$ generation (or the Millenium generation) and the $\mathrm{Z}$ generation are widely discussed in the scientific literature. Researchers believe that different generations require different approaches to the socialization of the younger generation, which poses completely new tasks for the higher school.

It should be noted that today in the category of youth in Russia (from 14 to 30 (35) years old), which represents the majority of applicants and students in Russian universities, the generation " $Y$ " and partly the generation " $Z$ " now fall. According to the agency Nielsen, the growing generation of $\mathrm{Z}$ is already more than $1 / 4$ of the total audience [14], which is important to take into account when designing new educational standards and the development of modern teaching technologies. It is important to remember that if the $\mathrm{Y}$ generation is the real basis of socio-economic and political life, then the generation of young people $Z$ is the future basis of the life of the country, which will form human capital taking into account the requirements of the digital global economy.

The key features of each generation, structured according to the age range, the main characteristics of the generation, key values and factors of their formation, and sources of information are presented in Table 2 .

Table 2. Characteristics of X-Y-Z Generations [15].

\begin{tabular}{|c|c|c|c|}
\hline $\begin{array}{c}\text { Character } \\
\text { istics }\end{array}$ & $\begin{array}{c}\text { Generation } \\
X \\
1965-1980\end{array}$ & $\begin{array}{c}\text { Millennial } \\
\text { Generation } \\
\text { (Generation } \\
\text { Y) } \\
\text { 1981-2000 }\end{array}$ & $\begin{array}{c}\text { Generation } \\
\mathrm{Z} \\
\text { "Digital } \\
\text { natives" } \\
\text { 2001-present }\end{array}$ \\
\hline $\begin{array}{c}\text { Age in } \\
2018, \text { years }\end{array}$ & $38-53$ & $18-37$ & $17-0$ \\
\hline $\begin{array}{l}\text { Characteris } \\
\text { tics of } \\
\text { generation }\end{array}$ & Skeptics & Realists & Idealists \\
\hline $\begin{array}{c}\text { Key values } \\
\text { of } \\
\text { generation }\end{array}$ & $\begin{array}{l}\text { readiness } \\
\text { for change; } \\
\text { choice; } \\
\text { global } \\
\text { awareness; } \\
\text { technical } \\
\text { literacy; } \\
\text { individualis } \\
\mathrm{m} \text {; the }\end{array}$ & $\begin{array}{c}\text { equal } \\
\text { competition; } \\
\text { leadership, } \\
\text { not } \\
\text { subordination } \\
; \\
\text { partnership, } \\
\text { not } \\
\text { subordination }\end{array}$ & $\begin{array}{l}\text { values in the } \\
\text { process of } \\
\text { formation }\end{array}$ \\
\hline
\end{tabular}




\begin{tabular}{|c|c|c|c|}
\hline & $\begin{array}{l}\text { desire to } \\
\text { learn; } \\
\text { informality } \\
\text { of views; } \\
\text { search for } \\
\text { emotions; } \\
\text { pragmatism } \\
\text {; } \\
\text { independen } \\
\text { ce; equality } \\
\text { of sexes. }\end{array}$ & $\begin{array}{c}\text {; } \\
\text { exchange of } \\
\text { information, } \\
\text { not its } \\
\text { protection; } \\
\text { making } \\
\text { decisions } \\
\text { based on } \\
\text { discussions } \\
\text { and peer } \\
\text { reviews, and } \\
\text { not blindly } \\
\text { following the } \\
\text { directions } \\
\text { from above. }\end{array}$ & \\
\hline $\begin{array}{l}\text { The main } \\
\text { events that } \\
\text { shaped the } \\
\text { values of } \\
\text { the } \\
\text { generation } \\
\text { in Russia } \\
\text { and the } \\
\text { world }\end{array}$ & $\begin{array}{l}\text { discontent } \\
\text { with power, } \\
\text { distrust of } \\
\text { managemen } \\
\text { t; } \\
\text { political } \\
\text { indifference } \\
\text {; } \\
\text { increase in } \\
\text { the number } \\
\text { of divorces; } \\
\text { an increase } \\
\text { in the } \\
\text { number of } \\
\text { women } \\
\text { mothers in } \\
\text { the } \\
\text { workplace; } \\
\text { extremely } \\
\text { low } \\
\text { population } \\
\text { growth; } \\
\text { reduction of } \\
\text { funding and } \\
\text { quality } \\
\text { reduction in } \\
\text { the } \\
\text { educational } \\
\text { system; } \\
\text { problems of } \\
\text { environmen } \\
\text { t and } \\
\text { ecology; } \\
\text { creation of } \\
\text { the Internet; } \\
\text { the end of } \\
\text { the Cold } \\
\text { War } \\
\text { of }\end{array}$ & $\begin{array}{l}\text { the collapse } \\
\text { of the USSR; } \\
\text { terrorist } \\
\text { attacks and } \\
\text { military } \\
\text { conflicts; } \\
\text { Increase in } \\
\text { consumption } \\
\text { by the } \\
\text { population of } \\
\text { the country, } \\
\text { and especially } \\
\text { youth, of } \\
\text { alcohol and } \\
\text { drugs; } \\
\text { development } \\
\text { of digital } \\
\text { technologies, } \\
\text { Internet }\end{array}$ & $\begin{array}{l}\text { integration } \\
\text { into the } \\
\text { world } \\
\text { community; } \\
\text { world } \\
\text { economic } \\
\text { crisis; } \\
\text { global } \\
\text { terrorism; } \\
\text { high } \\
\text { development } \\
\text { of modern } \\
\text { digital } \\
\text { technologies, } \\
\text { the Internet }\end{array}$ \\
\hline $\begin{array}{c}\text { Source of } \\
\text { informatio } \\
\mathrm{n} \text { about } \\
\text { politics }\end{array}$ & $\begin{array}{c}\text { Traditional } \\
\text { media }\end{array}$ & $\begin{array}{l}\text { Internet, } \\
\text { traditional } \\
\text { media }\end{array}$ & $\begin{array}{l}\text { Mobile } \\
\text { Internet, } \\
\text { Internet }\end{array}$ \\
\hline
\end{tabular}

Modern youth, represented by the generations of $Y$ and $\mathrm{Z}$, has a number of value characteristics and features of the perception of information that determine the trends in the development of higher education and determine the specifics of the use of new educational technologies. Undoubtedly, informatization fundamentally changes the key characteristics of the modern young generation. The growing generation of "electronic nomads" is surrounded by electronic devices from early childhood and does not perceive the information environment as something alien or external [16].

\section{Theory of Generations and the Problems of Modern Education: From Contradictions to Finding Solutions}

Based on the analysis of Russian and foreign studies, we will try to systematize the features of the educational process for different generations (Table 3).

Table 3. The educational process features for the X-Y-Z generations.

\begin{tabular}{|c|c|c|c|}
\hline $\begin{array}{l}\text { Characterist } \\
\text { ics of } \\
\text { educational } \\
\text { process }\end{array}$ & $\begin{array}{c}\text { Generati } \\
\text { on X } \\
1965- \\
1980\end{array}$ & $\begin{array}{c}\text { Millennial } \\
\text { Generation } \\
\text { (Generation } \\
\text { Y) } \\
\text { 1981-2000 } \\
\end{array}$ & $\begin{array}{c}\text { Generation } \\
\mathrm{Z} \\
\text { "Digital } \\
\text { natives" } \\
\text { 2001-present }\end{array}$ \\
\hline $\begin{array}{l}\text { Main events } \\
\text { that } \\
\text { determine } \\
\text { the specifics } \\
\text { of the } \\
\text { educational } \\
\text { system }\end{array}$ & $\begin{array}{l}\text { Changes } \\
\text { in the } \\
\text { paradigm } \\
\text { of } \\
\text { developm } \\
\text { ent of } \\
\text { higher } \\
\text { education } \\
\text { associated } \\
\text { with the } \\
\text { transition } \\
\text { to a } \\
\text { market } \\
\text { economy } \\
\text { system; } \\
\text { Reducing } \\
\text { funding } \\
\text { and } \\
\text { reducing } \\
\text { the quality } \\
\text { of } \\
\text { education } \\
\text { in the } \\
\text { education } \\
\text { system }\end{array}$ & $\begin{array}{l}\text { Transition to a } \\
\text { two-tier } \\
\text { education } \\
\text { system; } \\
\text { Reduction in } \\
\text { funding and } \\
\text { the growing } \\
\text { commercializa } \\
\text { tion of higher } \\
\text { education }\end{array}$ & $\begin{array}{l}\text { Transition to } \\
\text { a multi-level } \\
\text { system and } \\
\text { implementati } \\
\text { on of the } \\
\text { concept of } \\
\text { lifelong } \\
\text { learning }\end{array}$ \\
\hline $\begin{array}{l}\text { Axiological } \\
\text { basis of } \\
\text { education }\end{array}$ & $\begin{array}{l}\text { Academic } \\
\text { model } \\
\text { (knowled } \\
\text { ge of the } \\
\text { classics in } \\
\text { the } \\
\text { original, } \\
\text { ability to } \\
\text { hypothetic } \\
\text { al- } \\
\text { deductive } \\
\text { thinking) }\end{array}$ & $\begin{array}{c}\text { Competence } \\
\text { model } \\
\text { (knowledge, } \\
\text { skills) }\end{array}$ & $\begin{array}{l}\text { Model of } \\
\text { multiple } \\
\text { intelligence } \\
\text { (criteria are } \\
\text { specified in } \\
\text { the given } \\
\text { conditions) }\end{array}$ \\
\hline $\begin{array}{c}\text { Basic } \\
\text { principles of } \\
\text { the } \\
\text { educational } \\
\text { process }\end{array}$ & $\begin{array}{l}\text { Learning } \\
\text { through } \\
\text { research }\end{array}$ & $\begin{array}{l}\text { Training } \\
\text { through } \\
\text { specialized } \\
\text { competences }\end{array}$ & $\begin{array}{c}\text { Meta- } \\
\text { individuality }\end{array}$ \\
\hline $\begin{array}{l}\text { Completion } \\
\text { criterion }\end{array}$ & $\begin{array}{l}\text { Knowledg } \\
\text { e of the } \\
\text { classics in } \\
\text { the } \\
\text { original } \\
\text { and the }\end{array}$ & $\begin{array}{l}\text { Corresponden } \\
\text { ce to expected } \\
\text { competencies }\end{array}$ & $\begin{array}{l}\text { Creation of a } \\
\text { viable } \\
\text { product, } \\
\text { contribution } \\
\text { to the } \\
\text { development }\end{array}$ \\
\hline
\end{tabular}




\begin{tabular}{|c|c|c|c|}
\hline & $\begin{array}{c}\text { ability to } \\
\text { hypothetic } \\
\text { al- } \\
\text { deductive } \\
\text { thinking }\end{array}$ & & $\begin{array}{c}\text { of the } \\
\text { ecosystem of } \\
\text { society }\end{array}$ \\
\hline $\begin{array}{l}\text { Leading } \\
\text { channels for } \\
\text { obtaining } \\
\text { information }\end{array}$ & Offline & $\begin{array}{l}\text { Offline and } \\
\text { online }\end{array}$ & Online \\
\hline $\begin{array}{c}\text { Model of } \\
\text { "teacher- } \\
\text { student" } \\
\text { communicati } \\
\text { on }\end{array}$ & $\begin{array}{c}\text { Monologu } \\
\mathrm{e}\end{array}$ & $\begin{array}{l}\text { Dialogue, co- } \\
\text { creation }\end{array}$ & $\begin{array}{c}\text { Polylogue, } \\
\text { depersonaliza } \\
\text { tion, } \\
\text { interaction } \\
\text { through } \\
\text { constant mass } \\
\text { cooperation }\end{array}$ \\
\hline $\begin{array}{c}\text { Level of } \\
\text { information } \\
\text { literacy }\end{array}$ & Average & $\begin{array}{c}\text { Above } \\
\text { average }\end{array}$ & High \\
\hline $\begin{array}{c}\text { Features of } \\
\text { information } \\
\text { processing }\end{array}$ & $\begin{array}{c}\text { Mainly } \\
\text { passive } \\
\text { informatio } \\
n \\
\text { acquisitio } \\
\text { n, } \\
\text { advanced } \\
\text { critical } \\
\text { thinking } \\
\text { skills }\end{array}$ & $\begin{array}{l}\text { Passive-active } \\
\text { perception of } \\
\text { information, a } \\
\text { decrease in } \\
\text { the skills of } \\
\text { critical } \\
\text { information } \\
\text { analysis }\end{array}$ & $\begin{array}{l}\text { High speed of } \\
\text { obtaining } \\
\text { information, } \\
\text { ease of design } \\
\text { and } \\
\text { presentation, } \\
\text { along with } \\
\text { increased } \\
\text { "density" and } \\
\text { intensity of } \\
\text { information } \\
\text { flows, lack of } \\
\text { skills in } \\
\text { critical } \\
\text { information } \\
\text { analysis }\end{array}$ \\
\hline
\end{tabular}

Source: compiled by [10].

Let us consider some trends that shape the context of modern higher education.

The result of rapid development of information and communication technologies has become the virtualization of education. As the researchers rightly point out, virtual reality has become a part of life for the digital generation [17]. The leading channel for obtaining information has become an online channel, which gradually leads to the displacement of offline sources of information and a decrease in their authority in the eyes of modern youth. The transition from offline to online learning leads to the decentralization of educational resources and the growing influence of various types of online resources, sites and networked communities in the educational process. In addition, social networks, where the modern young generation "lives" most of the time, become a way of promoting educational services and a place for discussion of new educational practices.

Consumers received a lot of benefits from the development of the digital economy and education, in particular, although this effect is not directly reflected in GDP. For example, now you can at any time gain access to the knowledge that humanity has accumulated for centuries, or an unlimited flow of information in social networks, and completely free of charge.

Another trend is the change in the nature of "teacherstudent" communications in the learning process. According to Neborskiy (2017) [10], there is a transition from monologic communication to dialogue and in the future, to the polylogue and impersonal interaction. The role of the teacher changes from the "lecturer", "teacher", "mentor" figure to the figure of "assistant", "informer", "moderator", often virtual and impersonal. A unique model of communication is being formed in which the modern youth focuses not on passively absorbing information but on interaction, cooperation, including in the educational process, which is facilitated by the formation of numerous on-line platforms.

An important tendency of modern higher education, determined by the specifics of the perception of information of modern youth, is the speed of obtaining information, inherent in the young generation, the ease of design and presentation, along with the increase in the "density" and intensity of information flows. At the same time, despite the growth of communication opportunities and the best development of presentation skills, researchers note the inherent in the digital generation of a decrease in the skills of critical analysis and susceptibility to manipulation [18].

\section{Conclusions}

An attempt to present the trends of higher education through the prism of digitalization and the theory of generations reveals a number of contradictions inherent in the modern Russian system of higher education.

First, the discrepancy between the modern model of higher education and the goals and objectives of the digital economy (the university model 4.0). Thus, when setting targets for achieving the indicators of the Digital Economy Development Program, it is necessary to revise the basic settings that form the (determining) model

Secondly, the discrepancy between resources and technologies used in the educational process, the needs of the digital generation, their specific perception and processing of information. It is not just about technical and technological solutions, but also about the difference in communication models that determine the interaction between the teacher and the student.

Thirdly, we can observe the growing discrepancy between the level of information and technical literacy of the teachers of the older generation to the level of the younger generation. Young people are much better prepared and adapted to changes in the external environment dictated by the digitalization of socioeconomic space.

Fourth, there are growing contradictions, caused by the increase in the "density" and intensity of information flows. Undoubtedly, the young generation demonstrates excellent skills in terms of the speed of receiving and processing information. At the same time, in the context of the growing "cluttering" of the educational space by the influence of the Internet, the worsening of the skills of critical thinking and analyzing information (in my study - Novikova and Yuzefovich (2016) [18] convincingly show this trend). This of course leads to an increased risk of negative impact on young people, as reducing the critical perception makes the young generation open to various manipulations. 
Russian higher education will have to solve the complex task of matching the educational system with the challenges of the digital global economy. It is necessary not only to answer external challenges, but also to solve the internal tasks of digitalization of higher education. In this situation it is necessary to change not only the technical basis of the higher education system, but above all, critically comprehend the demands of the students and the role of the teacher, taking into account the needs of the digital economy.

A more global task facing the Russian higher school is a rethinking of the idea and, consequently, a model of higher education, which makes an actual scientific search in terms of understanding the new role and transformational tasks of higher education in the digital global economy.

\section{References}

1. C.N. Power, International Education Journal 1 (3), 152-163 (2000)

2. A.Aptekman, V.Kalabin, V.Klintsov, E.Kuznetsova, V.Kulagin, I.Yasenovets, Digital Russia: New Reality (McKinsey Report). Retrieved from https://www.mckinsey.com/en/ /media/McKinsey/L ocations/Europe\%20and\%20Middle\%20East/Russia /Our\%20Insights/Digital\%20Russia/Digital-Russiareport.ashx (July 2017)

3. J. Knight, Internationalization of Higher Education Practices and Priorities: 2003 IAU Survey Report. Retrieved from https://www.iauaiu.net/IMG/pdf/internationalisation_2003_0.pdf (2003)

4. H. de Wit, F. Hunter, International Higher Education 83, 6-8 (2016)

5. H.de Wit, Rationales for Internationalisation of Higher Education (Polytechnic Institute of Viseu, 1998). Retrieved from http://www.ipv.pt/millenium/wit11.html

6. J. Hudzik, Comprehensive Internationalization. From Concept to Action (NAFSA: Association of International Educators, Washington, D.C. , 2011)

7. G.G. Bubnov, N.G. Malyshev, E.V. Pluzhnik, V.I. Soldatkin, Cloud of Science 1, 5-9 (2013)

8. M.V. Boguslavsky, E.V. Neborskiy, Science 7(2) (2015)

9. N.S. Ladyzhets, E.V. Neborskiy, Science 7(2) (2015)

10. E.V. Neborskiy, The World of Science 5(4) (2017)

11. E.V. Neborskiy, Bulletin of the Udmurt University. Sociology. Political science. International relationships 1(2), 124-131 (2017)

12. N.Howe, W. Strauss, Millennials Rising: The Next Great Generation (Vintage Books, New York, 2000)

13. Th. C. Reeves and E. Oh, Generational Differences. Retrieved https://pdfs.semanticscholar.org/6881/902a7f82d572 abf1d3bc2a9bd94001288733.pdf

14. Portrait of modern consumers: Millenials are replaced by Generation $Z$. Retrieved from http://www.sostav.ru/publication/portretsovremennykh-potrebitelej-na-smenu-millenialamprikhodit-pokolenie-z-27485.html

15. V. Kovalev, I. Savelyeva, O. Falchenko, Presentism and Political Socialization of the Youth in the Global World, Medzinárodné vztahy 2017: Aktuálne otázky svetovej ekonomiky a politiky Zbornik príspevkov $z \quad 18$. medzinárodnej vedeckej konferencie konanej v Smoleniciach (2017)

16. N. Seliverstova, E. Iakovleva, O. Grigoryeva, The main trends Advances in Economics, Business and Management Research 38, 600-605 (2017)

17. A.A. Lisenkova, Values and Meanings, 3 (49), 2834 (2017)

18. I.A. Novikova, T.S. Yuzefovich, Individual and personal characteristics of users of different social networks, Digital society as a cultural and historical context of human development: a collection of scientific articles (State Social and Humanitarian University, Kolomna, 2016) 